\title{
Heavy Metal Concentration in Biotic and Abiotic Samples of Industrial Wastewater
}

\author{
Zeynep Aydoğan ${ }^{1}$, Ümit İncekara $^{2}$, and Ali Gürol ${ }^{3}$
}

\begin{abstract}
In the present study, some heavy elements (Ti, V, Cr, $\mathrm{Mn}, \mathrm{Fe}, \mathrm{Co}, \mathrm{Ni}, \mathrm{Cu}, \mathrm{Zn}, \mathrm{As}, \mathrm{Se}, \mathrm{Br}, \mathrm{Sr}, \mathrm{Pb}$ ) in sediment, water and their accumulation in some Hydrophilidae (Coleoptera) species organs (total body) were investigated. For this purpose, samples were collected from two industrial area in Erzurum (Turkey). Heavy elements levels in sediment, water and insect samples were analyzed by Energy Dispersive X-Ray Fluorescence (EDXRF) spectrometer. This study was firstly aimed to find out the level some heavy elements as the element pollution in selected stations, and secondly if Hydrophilidae (Coleoptera) species can be used as a biomonitor. The results pointed out that the insects were contaminated by the sediment and water, therefore hydrophilid beetles accumulate higher concentration of elements than their environment.
\end{abstract}

Keywords-Biomonitor, EDXRF, Heavy element, Hydrophilidae.

\section{INTRODUCTION}

$\mathrm{C}$ HEMICALS are part of our daily life. All living and inanimate matter is made up of chemicals. The pollution of the aquatic environment with heavy metals has become a worldwide problem during recent years, because they are indestructible and most of them have toxic effects on organisms [1]. Heavy metal concentrations in aquatic ecosystems are usually monitored by measuring their concentrations in water, sediments and biota [2], which generally exist in low levels in water and attain considerable concentration in sediments and biota [3]. Aquatic insects and other benthic invertebrates are the most widely used organisms in freshwater biomonitoring of human impact [4; 5], but studies on aquatic insects often focus on their larvae. Family Hydrophilidae, one of the largest families of Coleoptera, has wide distribution, well known taxonomy and its larvae require different environmental conditions, which makes these insects' good biomonitor for heavy element. The purpose of this study is a preliminary survey of the effect of anthropogenic activity on water, sediment and Hydrophilidae species and to certify the potential of these species as biomonitor for heavy element pollution in Erzurum.

\footnotetext{
${ }^{1-2}$ Atatürk University, Science Faculty, Biology Department, Erzurum, Turkey

${ }^{3}$ Atatürk University, Science Faculty, Physics Department, Erzurum, Turkey.
}

\section{MATERIALS AND METHODS}

\section{A. Collection of samples}

All samples were collected Cement and Sugar Factory wastewater. Insects were sampled from two sites, along with contiguous sediment and water. Insects were collected via 1 mm mesh aperture sieve and mouth aspirator. Three different species belonging to Hydrophilidae (Coleoptera) Hydrobius fuscipes (Linnaeus, 1758), Enochrus (Lumetus) quadripunctatus (Herbst, 1797) and Berosus (Enoplurus) spinosus (Steven, 1808) were determined. Sediments were taken from $30 \mathrm{~cm}$ depth benthic zone via plastic shovel, then stored in glass bottle and noted describing the information of the station. Before taking the water samples, the glass bottles were washed 4-5 times with the water in the study area. Location of the study areas were given in Table 1

\begin{tabular}{|c|c|c|c|}
\hline $\begin{array}{l}\text { Station } \\
\text { Number }\end{array}$ & $\begin{array}{l}\text { Altitu } \\
\text { de (m) }\end{array}$ & Location & Coordinates \\
\hline I & 1636 & $\begin{array}{l}\text { Cement } \\
\text { Factory } \\
\text { (Western } \\
\text { front) }\end{array}$ & $39^{\circ} 55^{\prime} 19 \mathrm{~N} 40^{\circ} 40^{\prime} 01 \mathrm{E}$ \\
\hline II & 1759 & Sugar Factory & $39^{\circ} 57^{\prime} 03^{\prime} \mathrm{N} 41^{\circ} 05^{\prime} 24 \mathrm{E}$ \\
\hline
\end{tabular}

\section{B. Elemental Analysis}

An EDXRF spectrometer with $1 \mathrm{Ci}{ }^{241} \mathrm{Am}$ radioactive source and an HPGe detector with resolution $\sim 180 \mathrm{eV}$ at 5.9 $\mathrm{keV}$ was used to determine the heavy elements in all samples. All measurements were carried out under vacuum. Measurement time for water and sediment samples was $4 \mathrm{~h}$ and insect samples was $24 \mathrm{~h}$. Insects were pulverised and then cellulose was added as a binder. Five tons of pressure applied to make $13 \mathrm{~mm}$ diameter pellets of each species. The concentration of elements in each samples were determined by Win AXIL software, which use Fundamental Parameters Method (FPM) for quantitative analysis.

\section{RESULTS AND DISCUSSIONS}

EXRF analysis one of the best analytical techniques to perform elemental analysis in all kind of samples no matter if liquids, solids or loose powders, also major, minor, thin and thick samples of all sizes and forms of samples. In this study the concentrations of elements were measured by Energy Dispersive X-Ray Fluorescence (EDXRF) spectrometry. In general, determined heavy element are shown in Table 2. The concentrations of these elements were found to vary in water, 
sediment and insects. Ti, $\mathrm{Cr}, \mathrm{Fe}, \mathrm{Ni}$ and $\mathrm{Pb}$ were measured in all samples of stations. It appears that Hydrophilidae species accumulated relatively more $\mathrm{Mn}, \mathrm{Fe}, \mathrm{Co}, \mathrm{Ni}, \mathrm{Cu}, \mathrm{Zn}$, As, Se, $\mathrm{Br}, \mathrm{Sr}$ and $\mathrm{Pb}$ compared to their environment. As it seen Table 2 E. quadripunctatus accumulated relatively more Ti, V, Co, $\mathrm{Ni}, \mathrm{Cu}, \mathrm{Zn}, \mathrm{As}$, Se and $\mathrm{Br}$ compared to the other species. In addition, these elements were the highest concentrations in $E$. quadripunctatus. B. spinosus accumulated highest concentration of $\mathrm{Cr}, \mathrm{Mn}$ and $\mathrm{Fe} ; H$. fuscipennis accumulated highest concentration of $\mathrm{Sr}$ and $\mathrm{Pb}$. In water samples $\mathrm{Ti}$ and $\mathrm{V}$ had highest concentration. In sediment samples Cr was highest concentration. Generally the heavy element concentration were observed as hydrophilid>sediment $>$ water. Ge, Ru, Rh, Pd, I, $\mathrm{Cs}$, Ce, Pr, Nd elements were qualitatively detected in some samples but their concentrations were quantitatively not determined due to the detection limit of spectrometer.

The data presented in the paper showed that the aquatic beetles are capable of reflecting trace elements bioaccumulation in habitats with different levels.

TABLE II: CONCENTRATION OF HEAVY ELEMENTS IN WATER, SEDIMENT AND INSECT SAMPLES (PPM)

\begin{tabular}{|c|c|c|c|c|c|c|c|c|}
\hline $\begin{array}{l}\text { Heavy } \\
\text { Element }\end{array}$ & Water & Sediment & $\begin{array}{l}\text { Station I } \\
\text { Hydrobius } \\
\text { fuscipes }\end{array}$ & $\begin{array}{l}\text { Enochrus } \\
\text { quadripunctatus }\end{array}$ & $\begin{array}{l}\text { Station II } \\
\text { Water }\end{array}$ & Sediment & $\begin{array}{l}\text { Enochrus } \\
\text { quadripunctatus }\end{array}$ & $\begin{array}{l}\text { Berosus } \\
\text { spinosus }\end{array}$ \\
\hline $\mathrm{Ti}$ & 443 & 2 & 130 & 133 & 242 & 1 & 15 & 1.5 \\
\hline $\mathrm{V}$ & 87 & 0.380 & 22.5 & 24 & 48 & - & 3 & - \\
\hline $\mathrm{Cr}$ & 20 & 855 & 22 & 20.5 & 11 & 487 & 0.7 & 582 \\
\hline Mn & 6.5 & - & 8 & 8 & 3.5 & - & 0.2 & 190 \\
\hline Co & 1 & - & 2.3 & 2.8 & 0.5 & - & - & - \\
\hline $\mathrm{Ni}$ & 0.5 & 20 & 0.66 & 0.63 & 0.32 & 12 & 128 & 12.5 \\
\hline $\mathrm{Cu}$ & 0.2 & 9.5 & 0.38 & 0.38 & 0.1 & - & 65 & 6.5 \\
\hline $\mathrm{Zn}$ & - & 5 & 0.34 & 0.21 & 0.1 & 3 & 50 & 6 \\
\hline $\mathrm{Pb}$ & 2 & 12 & 616 & 610 & 1 & 2 & 250 & 110 \\
\hline
\end{tabular}

\section{ACKNOWLEDGMENT}

The authors gratefully acknowledge the financial support of Ataturk University Scientific Research Project SRP-2012/162. This study is a part of first author Ph. D Thesis.

\section{REFERENCES}

[1] G. B. MacFarlane, and M. D. Burchettt, "Cellular distribution of $\mathrm{Cu}$, $\mathrm{Pb}$, and $\mathrm{Zn}$ in the Grey Mangrove Avicemnia marina (Forsk.)," Vierh Aquatic Botanic, vol. 68, pp. 45-59, 2000. http://dx.doi.org/10.1016/S0304-3770(00)00105-4

[2] M. Camusso, L. Vigano, R. "Baitstrini, Bioaccumulation of trace metals in rainbow trout,” Ecotox. Environ. Safe, vol. 31, pp. 133-141, 1995. http://dx.doi.org/10.1006/eesa.1995.1053

[3] H. N. Namminga, and J. Wilhm, "Effects of high discharge and an oil refinery cleanup operation bon heavy metals in water and sediments in Skeleton Creek," Proceedings of the Oklahoma Academy of Science, vol. 56, pp. 133-138, 1976.

[4] N. Bonada, N. Prat, V. H. Resh, B. Statzner, "Developments in aquatic insect biomonitoring: A comparative analysis of recent approaches," Annual Review of Entomology vol. 51, pp. 495-523, 2006. http://dx.doi.org/10.1146/annurev.ento.51.110104.151124

[5] Ü. İncekara, "Records of Aquatic Beetles (Helophoridae, Hydrophilidae, Hydrochidae, Dytiscidae) and Physico-Chemical Parameters in a Natural Lake (Artvin, Turkey),” Turk J Zool, vol. 33, pp. 89-92, 2009. 